\title{
Вступительный доклад
}

\section{РЕЗУЛЬТАТЫ ОПЕРАТИВНОГО ГЕОЛОГИЧЕСКОГО ОБСЛЕДОВАНИЯ}

\section{СИЛЬНЕЙШИХ ЗЕМЛЕТРЯСЕНИЙ РОССИИ В НАЧАЛЕ ХХІ ВЕКА}

\author{
Овсюченко А.Н., Рогожин Е.А
}

ФГБУН Институт физики Земли им. О.Ю. Шмидта РАН, 123242, г. Москва, Б. Грузинская ул., д. 10, e-mail:eurog1947@yandex.ru

Сейсмотектоническая группа ИФЗ РАН провела обследование эпицентральных областей сильнейших землетрясений, произошедших в разных регионах России в начале XXI века. Это такие сейсмические события, как Алтайское (M=7.3, 2003 г.), Олюторское (M=7.8, 2006 г.), два Тувинских $(\mathrm{M}=6.7,2011$ г. и $\mathrm{M}=6.8,2012$ г.) и к ковородинское $(\mathrm{M}=6.0,2011$ г.). Были закартированы сейсмодислокации разных типов, составлены детальные планы деформаций поверхности на наиболее представительных участках, проведено палеосейсмологическое изучение очаговой области. В ближней зоне на основе изучения плотности распределения сейсмодислокаций были построены изосейсты высших баллов. Подтвердилось представление о нарастании площади, охваченной сейсмогенными нарушениями, с ростом магнитуды главного толчка. Оценка длины сейсморазрывов и амплитуды смещения по ним в эпицентральных зонах четырех первых из перечисленных событий также показала рост этих параметров для более сильных землетрясений по сравнению с более слабыми. Результаты палеосейсмологически исследований позволили заключить, что в этих очагах в голоцене уже неоднократно имели место высокомагнитудные землетрясения. Радиоуглеродное датирование отобранных образцов захороненных палеопочв позволило оценить период повторяемости сильнейших толчков в этих же очагах и реконструировать долговременную сейсмическую историю охваченных современными землетрясениями регионов. Использование сейсмологических данных о распределении 
повторных толчков дало возможность построить трехмерную модель очагов. Алтайское, Тувинские и Сковородинское землетрясения возникли в соответствующих зонах балльности Карт ОСР-97, а люторское продемонстрировало ошибку карт типа «пропуска цели». Собранные данные составили основу для оценки сейсмической опасности изученных регионов на детальном уровне. 